\title{
Carbon isotope fluctuations in Precambrian carbonate sequences of several localities in Brazil
}

\author{
ALCIDES N. SIAL ${ }^{1 *}$, VALDEREZ P. FERREIRA ${ }^{1 *}$, AFONSO R. DEALMEIDA ${ }^{2}$, \\ ANTONIO W. ROMANO ${ }^{3}$, CLOVIS V. PARENTE ${ }^{2}$, \\ MARCONDES L. DACOSTA ${ }^{4}$ and VICTOR H. SANTOS ${ }^{1}$ \\ ${ }^{1}$ NEG-LABISE, Dept. de Geol., UFPE, C.P.7852, 50732-970 - Recife, PE, Brazil \\ ${ }^{2}$ Dept. de Geologia, UFCE, 60455-760 - Fortaleza, CE, Brazil \\ ${ }^{3}$ Instituto de Geociências, UFMG, 30430-120 - B. Horizonte, MG, Brazil \\ ${ }^{4}$ Centro de Geociências, UFPA, C.P. 1611, Belém, Pará, 66.075-900, Brazil
}

Manuscript received on March 9, 2000; accepted for publication on July 4, 2000; contributed by ALCIDES N. SiaL

\begin{abstract}
Carbon isotope fluctuations in Precambrian sedimentary carbonates between $2.8 \mathrm{Ga}$ and $0.60 \mathrm{Ga}$ in Brazil are examined in this study. The carbonate facies of the BIF of the 2.8 Ga-old Carajás Formation, state of Pará in northern Brazil, has rather homogeneous $\delta^{13} \mathrm{C}(-5 \%$ \% $\mathrm{PDB})$, compatible with carbonatization of a silicate protolith by a $\mathrm{CO}_{2}$-rich fluid from mantle degassing. The Paleoproterozoic Gandarela Formation, state of Minas Gerais, displays a narrow $\delta^{13} \mathrm{C}$ variation (-1.5 to $+0.5 \%$ ) compatible with carbon isotope signatures of carbonates deposited around 2.4 Ga worldwide. The Fecho do Funil Formation has probably recorded the Lomagundi $\delta^{13} \mathrm{C}$ positive anomaly $(+6.4$ to $+7.1 \%$ \% $\mathrm{PDB})$. The magnesite-bearing carbonates of the Orós mobile belt, state of Ceará, exhibit carbon isotope fluctuation within the range for carbonates deposited at $1.8 \mathrm{Ga}$.

The C-isotope record of the Frecheirinha Formation, northwestern state of Ceará, shows negative $\delta^{13} \mathrm{C}$ values in its lower portion $(-2 \%$ ) and positive values up section ( +1 to $+3 \%$ ), which suggests this sequence is a cap carbonate deposited after a glacial event around $0.95 \mathrm{Ga}$. The Jacoca and Acauã sedimentary carbonate Formations, state of Sergipe, NE Brazil, show carbon isotope fluctuations very similar to each other (average around $-5 \% \circ$ ), compatible with a deposition around $0.76 \mathrm{Ga}$. The younger Olho D'Água carbonate Formation, however, also in the state of Sergipe, displays negative $\delta^{13} \mathrm{C}$ values at the lower portion of the Formation, changing dramatically up section to positive values as high as $+10 \%$, a characteristic compatible with a Sturtian cap carbonate deposited around $0.69 \mathrm{Ga}$.

On the light of the $\mathrm{C}$ isotope data discussed in this study, it seems that $\delta^{13} \mathrm{C}$ fluctuations in Paleoproterozoic carbonates in Brazil are within the range found globally for metasedimentary carbonates of this age. Carbon isotope data proved to be very useful in establishing relative chronology of Neoproterozoic carbonate formations for which precise radiometric ages are not available.
\end{abstract}

Key words: carbon isotopes, carbonates, chemostratigraphy, Archean, Paleoproterozoic, Neoproterozoic.

\section{INTRODUCTION}

\footnotetext{
* Member of the Academia Brasileira de Ciências Correspondence to: Alcides N. Sial

E-mail: ans@npd.ufpe.br
}

Carbon isotope studies of sedimentary rocks and their metamorphic equivalents have provided impor- 
tant information about the exogenic $\mathrm{C}$ cycle throughout Earth history (Veizer \& Hoefs 1976, Knoll et al. 1986). Besides, the carbon isotope stratigraphy has been one of the most powerful tools in Precambrian chronostratigraphy, especially when sediments lack recognizable animal fossils (Kaufman 1998) or are radiometrically undatable. According to this author, temporal variations of $\delta^{13} \mathrm{C}$ are interpreted as the product of long-term changes in the proportion of organic matter to carbonate buried in sediments. Carbon isotope variations may reflect episodic introduction of ${ }^{12} \mathrm{C}$ into the ocean surface or almost complete cessation of biological productivity.

A $\delta{ }^{13} \mathrm{C}$ (PDB) chemostratigraphic curve for marine carbonates has been compiled by Hoffman et al. (1998a) starting at $2.5 \mathrm{Ga}$. A widespread positive $\delta^{13} \mathrm{C}$ anomaly in the age interval of 2.33-2.06 Ga age has been recognized (Baker \& Fallick 1989a, b, Melezhik \& Fallick 1994, Melezhik et al. 1997, Hoffman et al. 1998a). The remainder of the Paleoproterozoic (2.0 to $1.6 \mathrm{Ga}$ ) and most of the Mesoproterozoic show $\delta^{13} \mathrm{C}$ near $0 \%$ opDB, with slightly positive values in the 1.1-1.0 Ga age interval (Hoffman et al. 1998a). More recently, Kha et al. (1999) studied carbonates of the Bylot Supergroup, Baffin Islands, Canada (1.27 to $0.72 \mathrm{Ga}$ ) and compiled new and published data improving the Mesoproterozoic to earliest Neoproterozoic global carbon isotopic curve for this interval. In the Neoproterozoic, the $\delta^{13} \mathrm{C}$ secular variation curve shows strong positivenegative excursions, four of the major negative ones being interpreted as the stratigraphic position of ancient ice ages which led to a more elaborated theory of Snowball Earth (Hoffman et al. 1998b, Hoffman $\&$ Schrag 2000). Figure 1 represents a compilation of the two above-mentioned secular $\delta^{13} \mathrm{C}$ variation curves.

The two most striking phenomena recorded by $\mathrm{C}$ isotopes in the Proterozoic are the widespread positive $\delta^{13} \mathrm{C}$ anomaly in the $2.33-2.06 \mathrm{Ga}$ interval (Lomagundi or Jatulian event) and the striking climate reversal with glacial deposits (four glaciations) blanketed by carbonate rocks between $0.75 \mathrm{Ga}$ and $0.58 \mathrm{Ga}$ ago (Sturtian-Vendian periods) with strong
$\mathrm{C}$ isotopic excursions. The isotopically heavy carbonates in the Lomagundi event $\left(\delta^{13} \mathrm{C}\right.$ up to $\left.17 \%\right)$ are linked with the explosion of stromatolites, expressed as a peak in the abundance and taxonomic diversity of stromatolites (Melezhik et al. 1997). In the Neoproterozoic, the fragmentation of the ancient Rodinia supercontinent was accompanied by intermittent, but widespread glaciation in the $0.75-0.55$ Ga interval. The isotopic excursions are enormous in this time interval in comparison to excursions in the preceding 1.2 billion years or in the Phanerozoic (Hoffman et al. 1998b). In this age interval, it is common to observe post-glacial carbonate rocks even in terrigenous-dominated sections.

The major scope of this work includes: (a) study of the fluctuation of carbon isotopes in some Precambrian metasedimentary carbonates in Brazil and how these fluctuations fit to variations of the global C isotopic curve; (b) regional correlation of some Neoproterozoic diamictites/carbonates in Brazil with other continents that once were part of the Gondwana supercontinent (e.g. West Africa) and (c) inferring the age of some Neoproterozoic metasedimentary carbonate sequences on the basis of their carbon isotope fluctuations versus the $\delta^{13} \mathrm{C}$ (PDB) chemostratigraphic curve for Neoproterozoic marine carbonates.

\section{SAMPLING PROCEDURE, LOCALITIES AND ANALYTICAL METHODS}

The $\delta^{13} \mathrm{C}$ stratigraphy of carbonate sequences from several localities in Brazil examined in this study includes the Carajás Formation, in the northern region of the country three Paleoproterozoic sequences (Gandarela and Fecho do Funil Formations, Minas Gerais, eastern Brazil, and magnesite-bearing carbonates of the Orós mobile belt, Ceará, northeastern Brazil) and six Neoproterozoic Formations in northeastern Brazil (Frecheirinha and São José in Ceará, and Jacoca, Olho D'Água, and Acauã, state of Sergipe, and Traipu-Jaramataia, state of Alagoas). The approximate location of the study areas is shown in Fig. 2.

A total of almost five hundred carbonate rock 


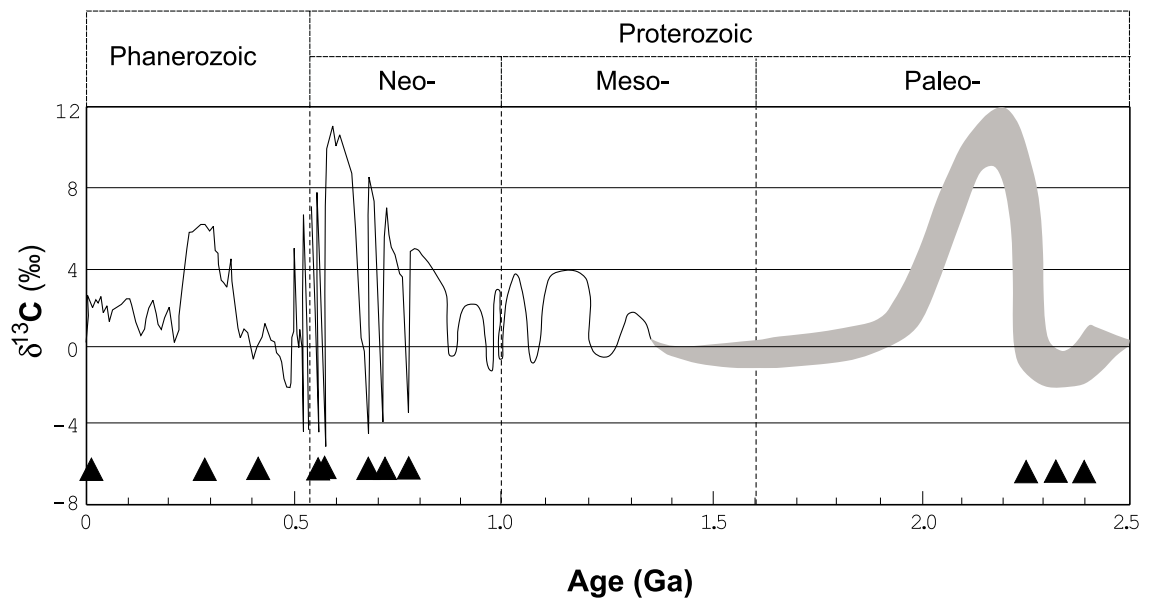

Fig. 1 - Compilation of the secular $\delta^{13} \mathrm{C}$ variation curves based on Hoffman et al. (1998a) and Kha et al. (1999). The thin black line corresponds to the well-constrained Later Neoproterozoic carbon isotopic curve (Hoffman et al. 1998a), while the thicker gray line represents a preliminary compilation of carbon isotopic compositions (Hoffman et al. 1998a, Kha et al. 1999). Triangles indicate glacial events.

samples were collected along traverses, perpendicular to the strike of the bedding (or major foliation in some cases), at a metric to centimetric scale, from the Precambrian metasedimentary carbonate sequences in this study.

$\mathrm{CO}_{2}$ gas was extracted from powdered carbonates in a high vacuum line after reaction with $100 \%$ phosphoric acid at $25^{\circ} \mathrm{C}$ for one day (three days in the case of dolomite, calcite-dolomite mixtures or ankerite), and cryogenically cleaned, according to the method described by McCrea (1950). $\mathrm{CO}_{2}$ gas released was analyzed for $\mathrm{O}$ and $\mathrm{C}$ isotopes in a double inlet, triple collector SIRA mass spectrometer, using the BSC reference gas (Borborema skarn calcite) that was calibrated against NBS-18, NBS19 and NBS-20 standards, and has a $\delta^{18} \mathrm{O}$ value of $-11.28 \%$ opd and $\delta^{13} \mathrm{C}=-8.58 \%$ \% cision of the method has been assessed by repeated analyses of the BSC reference gas and the accuracy by comparison of NBS standards. The results are expressed in the notation $\delta \%$ (per mil) in relation to the international PeeDee belemnite (PDB) scale.

Carbon isotope compositions of most of the bulk rock probably do not change much during di- agenesis because the volume of carbon within the carbonate rock is vastly greater than that in the porewater reservoir and because the fractionation between calcium carbonate is relatively small at nearsurface temperatures (Emrich et al. 1970, Scholle \& Arthur 1980). Most metasedimentary carbonates in this study have been submitted to sub-greenschist to greenschist facies metamorphism with only one exception (Traipu-Jaramatia Formation) that has been submitted to amphibolite facies metamorphism.

\section{ARCHEAN SEDIMENTARY CARBONATE ROCKS}

Sea water yields an integrated and weighted global signal of events shaping the development of the solid Earth, life, ocean and air (Veizer et al. 1989a). These signals are encoded in chemical sediments precipitated from ancient oceans and, in particular, isotopic signatures of oxygen, carbon, sulfur and strontium are important tools in deciphering these signals. The chemistry of the Archean oceans has been buffered by the so-called "mantle" flux, that is, by pervasive interaction with oceanic crust $\left(\delta^{13} \mathrm{C}\right.$ of $-4 \pm 2 \%$ opDB ; Veizer et al. 1989b).

Sedimentary carbonates are a relatively minor 


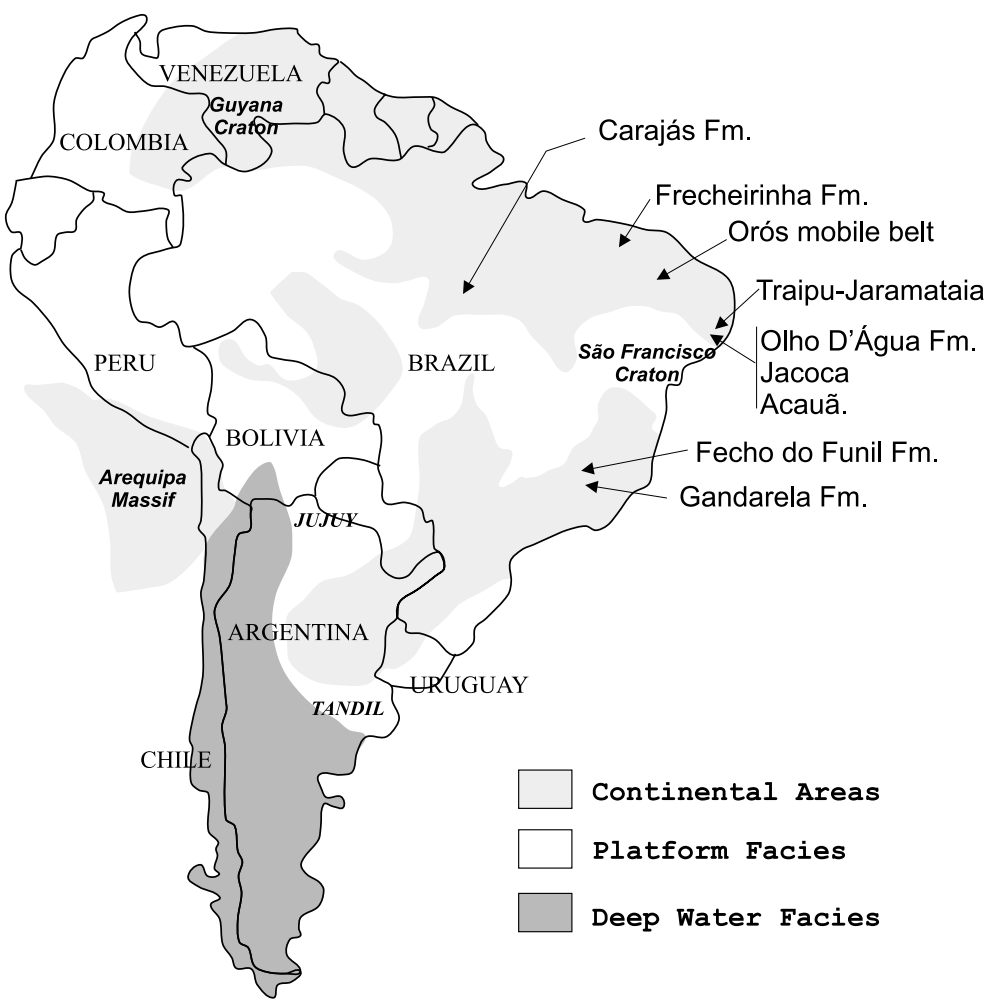

Fig. 2-Geographic location of sampled stratigraphic units in the present study: Carajás Formation, state of Pará, Frecheirinha and São José Formations, state of Ceará, Acauã, Jacoca, Olho D’Agua, state of Sergipe, Traipu-Jaramataia, state of Alagoas, and Gandarela and Fecho do Funil Formations, state of Minas Gerais. In this Figure, it is also indicated the distribution of Neoproterozoic carbonate rocks in South America, and a possible paleographic scheme during the Vendian (adapted from Aceñolaza \& Durand 1987).

component of Archean greenstone belts. Even so, these rocks are important because they recorded chemical and isotopic properties of the coeval oceans. Most Archean carbonates described in the literature are regarded as of hydrothermal origin (e.g. Superior and Slave provinces of Canada, Kapvaal Craton of South Africa and Pilbara block of Australia) from field criteria, that is, they resulted from carbonatization of silicate protoliths. Only few exceptions are known (e.g. Steep Rock Lake, Ontario, Canada) where a 3.0 Ga-carbonate platform succession, 500m thick, was deposited by a combination of chemical and biological processes (Veizer et al. 1989b, Kushy \& Hudleston 1998).
The best estimate for $\delta^{13} \mathrm{C}$ for the Archean sedimentary carbonates $(3.5 \mathrm{Ga}$ and $2.8 \pm 0.2 \mathrm{Ga})$ is about $+1.5 \pm 1.5 \%$ o (Veizer et al. 1989b). In the present study, we have selected carbonate rocks associated with the banded iron formation of Carajás, state of Pará, northern Brazil, for carbon and oxygen isotope determinations.

1. The Carajás Formation (2.76 Ga), state of PARÁ, AMAZON REgION

The Carajás mineral province, northern Brazil (Fig. 3 ) is known for its iron mineralization from lateritic weathering of banded iron formations (BIF) 


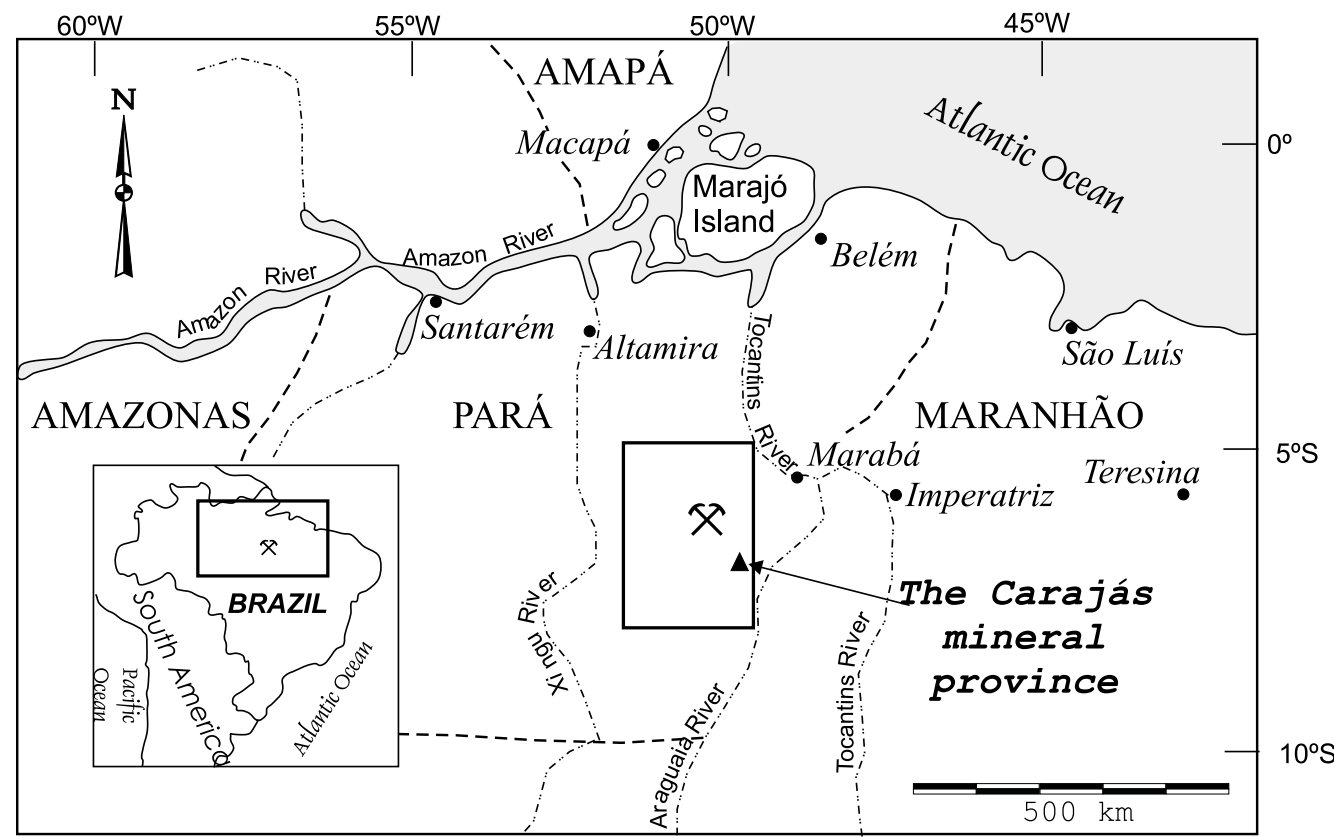

Fig. 3 - Location map of the Carajás mineral Province Formation, state of Pará, northern Brazil (crossed hammers for the location of N4E iron deposit). Modified from Teixeira et al. (1997).

and as the site for one of the largest operating iron mines in the world. The Carajás BIF constitute the Carajás Formation of the Grão Pará Group, a $2.76 \mathrm{Ga}$ volcano-sedimentary belt (Machado et al. 1991). This Group is the main stratigraphic unit of the Serra dos Carajás and carries iron and manganese protores and ores. The Grão Pará Group is constituted by the predominantly volcanic $\mathrm{Pa}$ rauapebas (basalts and subordinate rhyolites), Carajás (BIF and basaltic sills), Igarapé Cigarra (basalts, BIF, tuffs, sandstones and cherts) and Igarapé Boa Sorte (siltites and shales) Formations. There is no evidence of regional metamorphism in these rocks, basalts displaying well-preserved igneous textures.

The Carajás Formation is $220 \mathrm{~m}$ thick in the N4E iron mine. Recent drillings in this mine revealed carbonate-rich jaspilites that, perhaps, correspond to the carbonate facies of these BIF. Unmetamorphosed jaspilites exhibit milli- to centimetric bands of hematite/magnetite alternating with bands of jasper/chert/ chalcedony. The carbonatic jaspilite is brown to dark gray, with preserved millimetric banding, locally folded, faulted and brecciated. The carbonate (dolomite, calcite) appears as light gray bands as well as in veinlets that cut the bedding. Hematite and pseudomorphs of magnetite are, mostly, corroded and partially replaced by carbonates. Dolomite and calcite are the main carbonate minerals.

Oxygen isotope data display $\delta^{18} \mathrm{O}$ values from -24 to $-10 \%$ opB, predominating values between -15 to $-10 \%$. The twenty five analyzed samples from drill-holes display $\delta^{13} \mathrm{C}$ predominantly around $-5 \%$ о $\mathrm{PDB}$ (total variation from -3 to -6 ; Fig. 4), distinctly lighter than the inferred value for normal Archean seawater $\delta^{13} \mathrm{C}$ (near zero) (Veizer et al. 1990).

Similar values were observed in $\delta^{13} \mathrm{C}$ in the carbonate facies associated with the Archean Temagami banded iron formation in Canada (Bowins \& Crocket 1994) which is about the same age as the Carajás BIF. Beukes et al. (1990) have proposed that basinal waters may be stratified with respect to carbon isotopic composition in response to hy- 


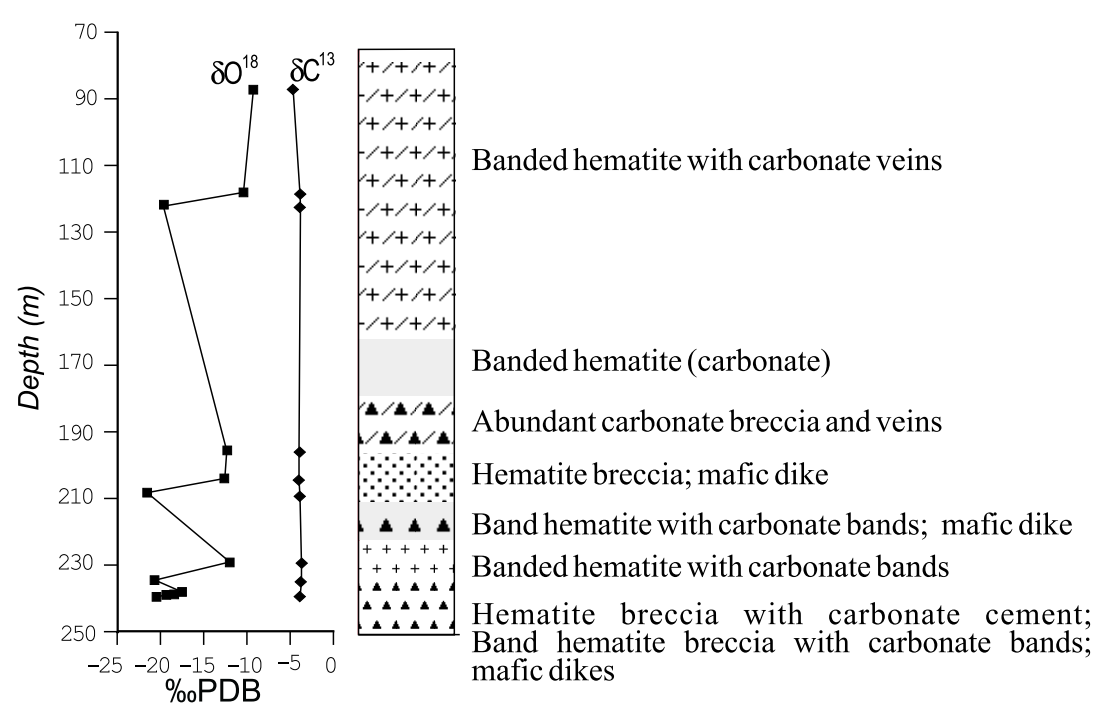

(a)

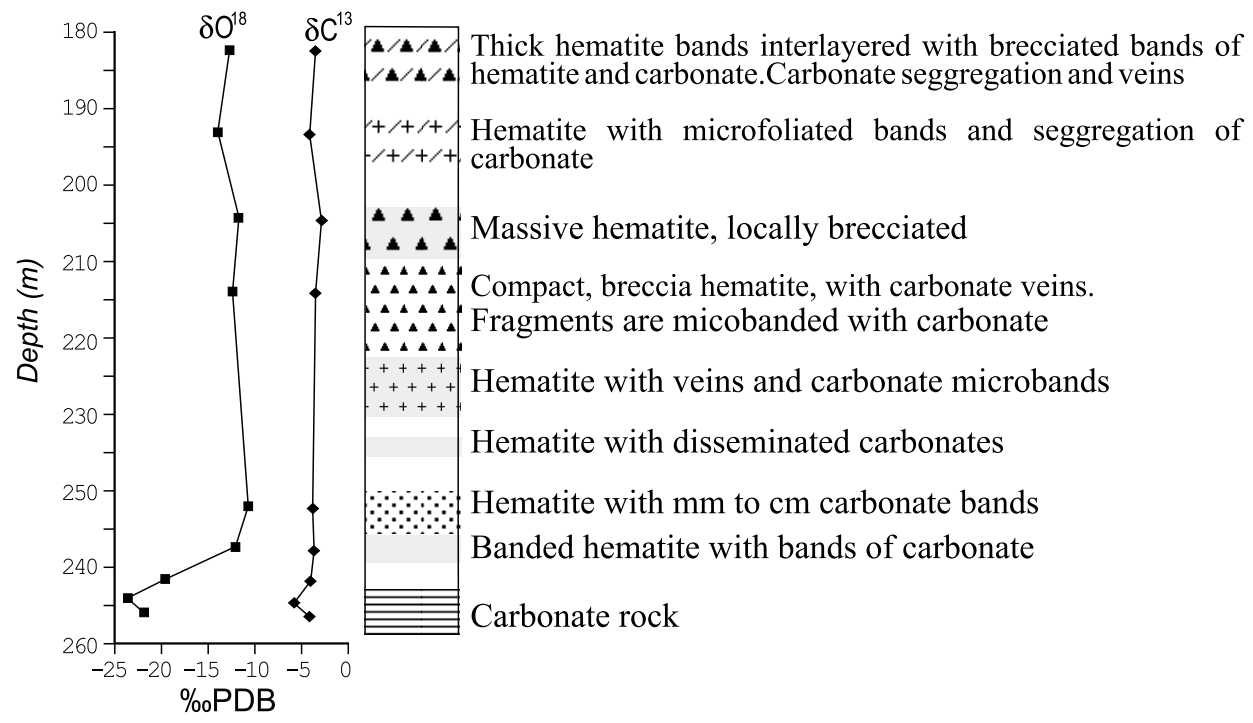

(b)

Fig. 4 - (a) and (b) Carbon and oxygen isotope profiles of the carbonatic jaspilite of the Carajás Formation sampled in drill holes in the N4E iron deposit, state of Pará.

drothermal fluid input, with deeper basinal waters characterized by lighter carbon $\left(\delta^{13} \mathrm{C} \approx-5 \%\right.$ คDB $)$ compared to surface waters $\left(\delta^{13} \mathrm{C} \approx 0 \%\right.$ opD $)$. If this was the case for the Carajás carbonates, it is possible that one is dealing with sedimentary carbonates equilibrated with deep basinal water. The Earth's mantle in the Archean was probably the main source for $\mathrm{CO}_{2}$ and these rocks likely retained a $\delta^{13} \mathrm{C}$ 
mantle signature $(-5 \%$ \%DB $)$. This $\mathrm{CO}_{2}$-rich fluid could be from mantle degassing or recycling of $\mathrm{C}$ in a subduction-related environment.

\section{PROTEROZOIC SEDIMENTARY CARBONATES}

In comparison to Archean oceans, Proterozoic and Phanerozoic oceans have been buffered mostly by river flux (Veizer et al. 1989a), which implies a much more pronounced $\mathrm{C}$ isotopic variation than that observed in Archean carbonates. In consequence, positive excursions to anomalously high $\delta^{13} \mathrm{C}$ have been identified in Paleoproterozoic and Neoproterozoic strata. The Paleoproterozoic positive $\delta^{13} \mathrm{C}$ anomaly (Lomagundi event) in sedimentary carbonate rocks or in their metamorphic equivalents has been kept as a single event which lasted for about 260 million years. Buick et al. (1998), however, detected three positive $\delta^{13} \mathrm{C}$ anomalies in Paleoproterozoic sedimentary carbonates in the Kapvaal craton (2.43 to $1.93 \mathrm{Ga}$ interval). Unfortunately, from his work, it was not clear whether these excursions reflect a global or a local process.

\section{A) Paleoproterozoic Sedimentary Carbonate SEQUENCES}

\section{The Gandarela Formation (2.4 Ga), Quadri-} ŁÁtero Ferrífero, Minas Gerais

The Minas Supergroup is a large sedimentary sequence with a basal unit of clastic rocks (conglomerates, quartzites and phyllites of the Caraça Group), a middle unit composed of chemical rocks (iron formation and carbonates of the Itabira Group) and an upper unit of interlayered clastic and chemical rocks (Piracicaba Group). The Itabira Group has extensive banded iron formations and is divided into the Cauê and Gandarela Formations. The latter consists, dominantly, of carbonate rocks deposited in shallow water, and has a total thickness of $\sim 500 \mathrm{~m}$. In the Gandarela Syncline, stromatolitic structures occur in the intermediate member of the Gandarela Fm. A $\mathrm{Pb}-\mathrm{Pb}$ isochron age of $2.42 \pm 0.02 \mathrm{Ga}$ was reported by Babinski et al. (1995).

About 60 carbonate samples were sam- pled from four sections around the Gandarela Farm (Fig. 5). These carbonate rocks are gray, buff to red dolomites $(\sim 60 \mathrm{~m}$ thick, next to the base of this carbonate sequence, in contact with iron formations) to limestones which present light and dark-gray alternating bands on a cm scale and, locally, display stromatolitic structure. In this sequence, $\delta^{13} \mathrm{C}$ values vary from -1.6 to $+0.4 \%$ орDB. The reddish dolomites, at the base of the Formation, display the most negative values $(-1$ to $-1.3 \%$ о PDB $)$ followed upsection by positive values (average $+0.3 \%$ PDB ), limited to the buff dolomites, and succeeded, immediately above an intraformational breccia, by slightly negative values $(-0.3 \%$ ०DB $)$ in buff, slightly clay-rich dolomites (Fig. 6b). The Cisotope variation in this Formation lies within the range for carbonates of this age in the $\mathrm{C}$-isotope secular variation curve in Fig. 1. Oxygen isotope ratios vary from -6.6 to $-10.4 \%$ \% of the dolomitic portions of this sequence average $-7 \%$ PDB, while the more calcitic portions average $-9 \%$ о PDB. Regarding the very low grade of metamorphism these rocks underwent, these data, perhaps, reflect environmental variations during limestone deposition.

\section{The Fecho do Funil Formation, Piracicaba Group, Minas Gerais (2.1 Ga)}

This Formation is represented by an association of terrigenous and chemical sedimentary platform facies. Light-gray, greenish and pinkish dolomitic rocks form a $60 \mathrm{~m}$ thick lens with poorly preserved columnar stromatolite structures, exposed at the top of the sequence. $\mathrm{A} \mathrm{Pb}-\mathrm{Pb}$ isochron minimum age of $2.11 \pm 0.1 \mathrm{Ga}$ for this Formation has been reported (Babinski et al. 1995).

Three representative samples from Morro do Bule locality, near Ouro Preto town (Fig. 5), were analyzed for $\mathrm{C}$ and $\mathrm{O}$ isotopes in this study. $\delta^{13} \mathrm{C}$ values in these rocks vary from +6.4 to $+7.1 \%$ ०DB while $\delta^{18} \mathrm{O}$ varies from -9.4 to $-9.1 \%$ opDB. The $\delta^{13} \mathrm{C}$ values are within the $\mathrm{C}$-isotope range for 2.1 Ga sedimentary carbonates (Hoffman et al. 1998a), and strongly suggests that the Lomagundi event was 


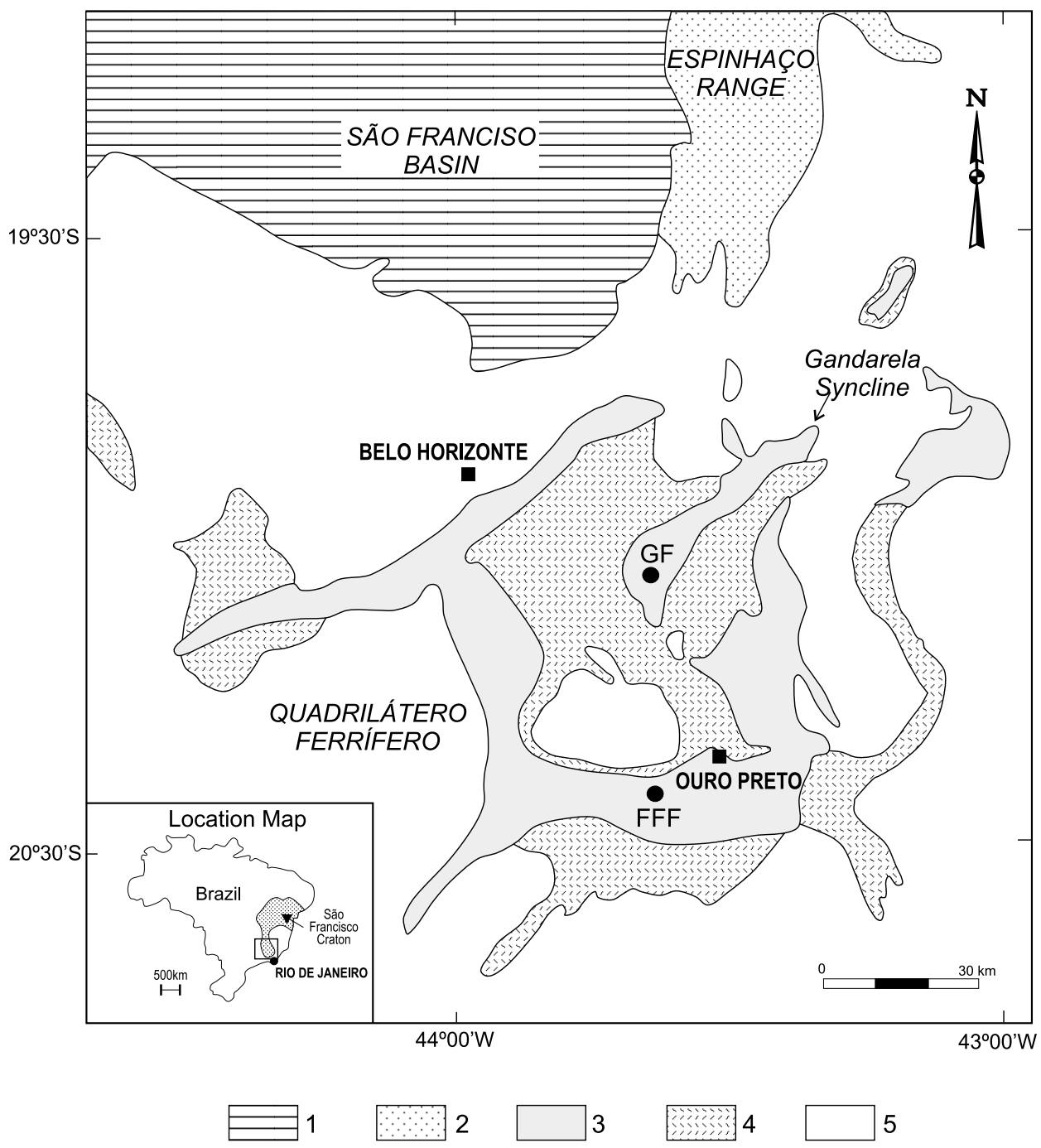

Fig. 5 - Simplified map of the Quadrilátero Ferrifero (modified from Inda et al. 1984, Babinski et al. 1995), state of Minas Gerais. The two sampled localities (Gandarela Farm) and Morro do Bule are indicated by solid circles. GF $=$ Gandarela Formation, FFF $=$ Fecho do Funil Formation. $1=$ Minas Supergroup; 2 = Rio das Velhas Supergroup; 3 = Minas Supergroup; 4 = Rio das Velhas Supergroup; 5 = granite-gneiss terranes.

recorded in sedimentary carbonates of this age in South America. This suggests depositional conditions similar to that prevailing during the deposition of sedimentary carbonates of equivalent age in the Lomagundi Formation in Zimbabwe (Schidlowski et al. 1976), Kapvaal craton, and in dolostones of the Aravalli Supergroup in the Aravalli craton in India (Fig. 7; Maheshwari et al. 1999).
3. The Magnesite-bearing metasedimentary Carbonates of the Orós Mobile Belt, Ceará (1.8 GA)

The Orós mobile belt represents a sigmoidal, continuous linear zone which extends for about $500 \mathrm{~km}$ with a width from 2 to $13 \mathrm{~km}$ in the central part of the Borborema Province, NE Brazil (Fig. 8), in the state of Ceará. This belt is characterized by greenschist 


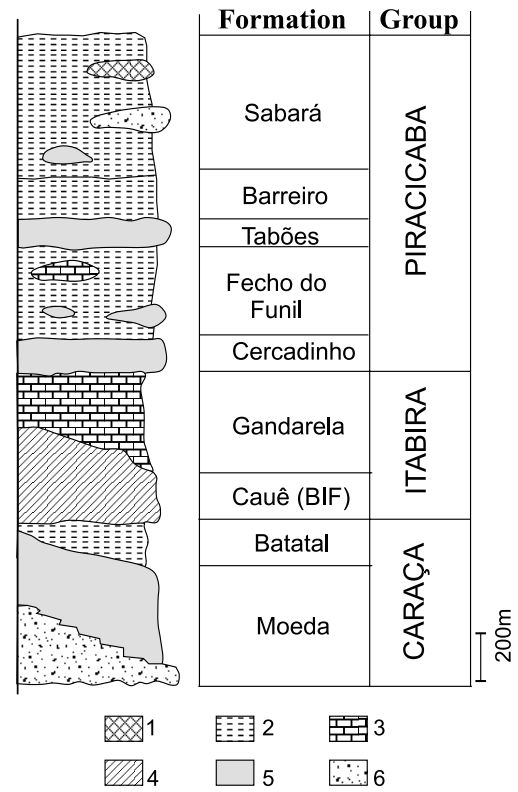

(a)

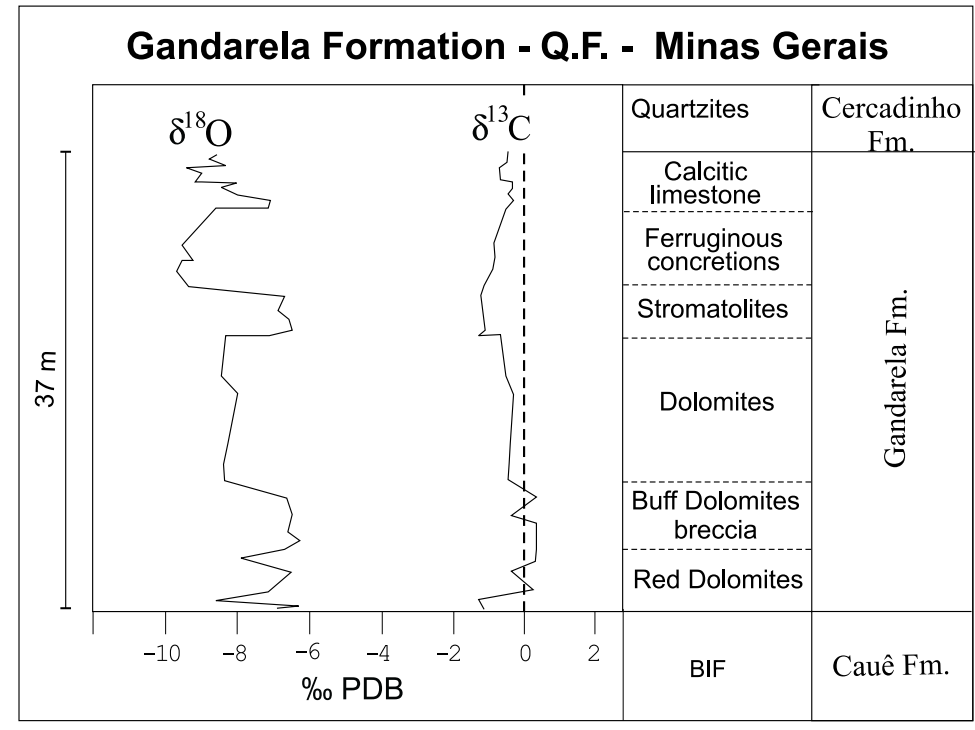

(b)

Fig. 6 - (a) Lithostratigraphy of the Minas Supergroup, state of Minas Gerais (Babinski et al. 1995). 1= graywackes, $2=$ phyllites, 3 = carbonate rocks, 4 = banded iron formations, $5=$ quartzites, $6=$ conglomerates; (b) Composite carbon and oxygen isotope profiles for the Early Paleoproterozoic Gandarela Formation at the Gandarela Farm.

to amphibolite-facies metavolcano-sedimentary sequences intruded by Meso- to Neoproterozoic granitoids. Calcitic, dolomitic and magnesitic marbles occur in discontinuous lenses for about $140 \mathrm{~km}$ in the domain of this belt between Alencar (Ceará) and Pio IX (Piaui) villages. These marbles represent evaporites deposited in a shallow marine environment (Parente \& Arthaud 1995). Zircons from metarhyolites of this belt yielded a U-Pb age of $1.79 \pm 0.1 \mathrm{Ga}$ (Van Schmus et al. 1995), probably corresponding to the age of sedimentation.

The metacarbonate sequence is very abundant and more calcic in the southwestern extremity of the belt, but less voluminous and more magnesian towards the northeastern portion of the belt, the highest $\mathrm{Mg}$ contents being observed in the Alencar-Orós region. Magnesite deposits pass gradually into metadolomites and then to almost pure calcitic marbles westward the belt.
Sixteen calcitic to dolomitic carbonate samples from this discontinuous set of magnesian metacarbonate rocks display $\delta^{13} \mathrm{C}$ values from -3.2 to $+2.1 \%$ \%DB. The calcitic limestones, deposited on open-marine environment, the older of these carbonate sequences, display positive $\delta^{13} \mathrm{C}(+0.5$ to $+2.1 \%$ ) while dolomitic marbles to dolostones, deposited on less-open marine environment, display negative shift $(-0.7$ to $-3.2 \%$ o PDB $)$. This total $\delta^{13} \mathrm{C}$ variation is within the limits for $1.8 \mathrm{Ga}$-old carbonate rocks. The calcitic marbles display $\delta^{18} \mathrm{O}$ values from -6.5 to $-10 \%$ $\%$ PDB , while the dolomitic ones have values in the -10 to $-15 \%$ o PDB range. Oxygen isotope ratios were probably modified at greenschist to amphibolite-facies metamorphic conditions and, therefore, are of little use in tracing the thermal history of the carbonate deposition.

\section{B) Neoproterozoic Metasedimentary Carbon- ATE SEQuences}




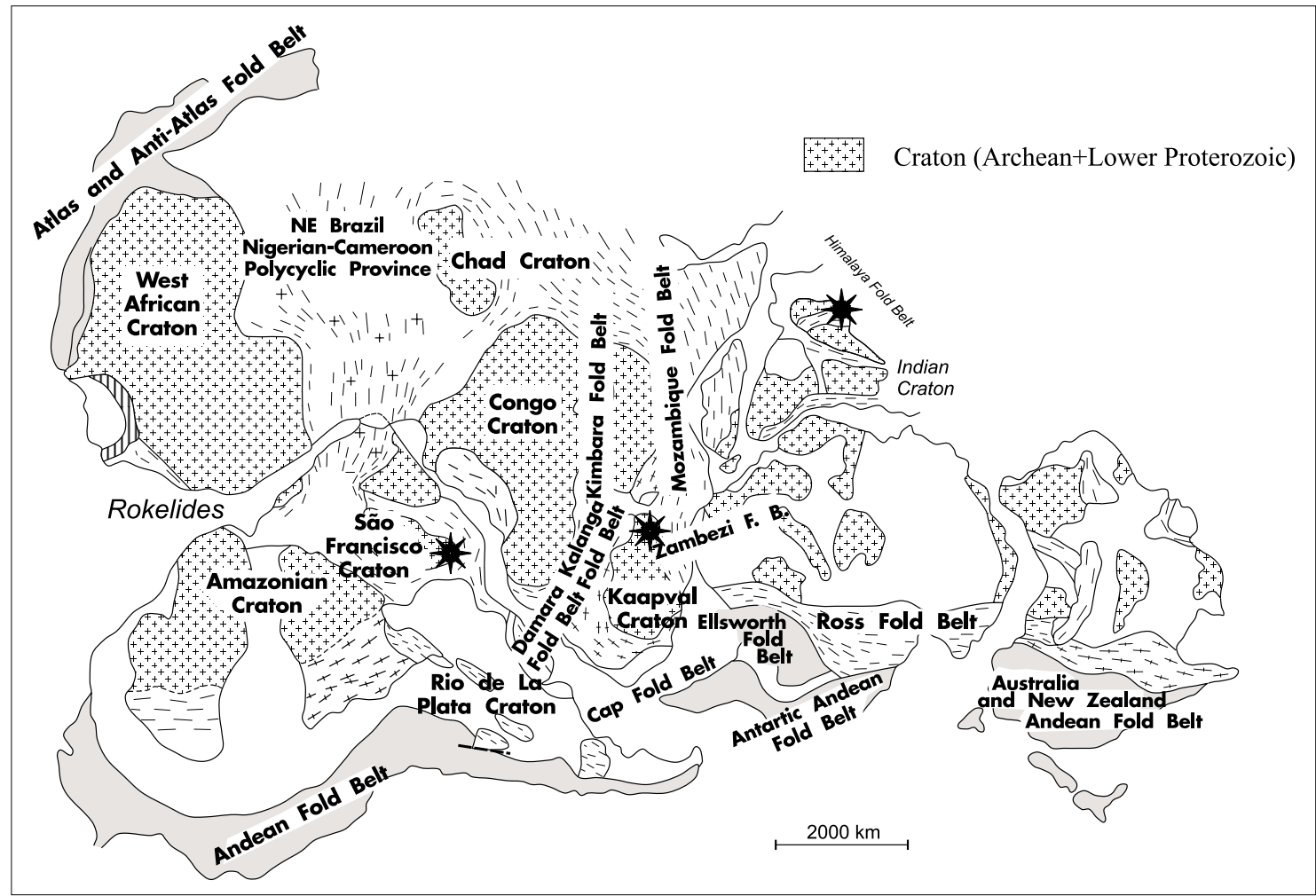

Fig. 7 - Schematic structural map of Gondwana (modified from Trompette 1994) showing the geographic distribution of cratons and foldbelts. Stars: Paleoproterozoic Formations where the Lomagundi event has been recorded (Fecho do Funil Fm., Minas Gerais, Brazil; Lomagundi Fm., Zimbabwe, Africa, and the Aravalli Supergroup, Aravalli craton, India).

The C-isotope stratigraphy of some Neoproterozoic metasedimentary carbonate sequences in northeastern Brazil are discussed below, including the Frecheirinha and São José Formations, NW Ceará; Jacoca, Acauã, and Olho D’Água Formations, Sergipe, and Traipu-Jaramataia Formation, Alagoas. Together with other correlative deposits (e.g. Paranoá-Bambuí Groups in central Brazil, Santos et al. in press, the Una Group, Irecê Basin, Bahia, Misi \& Veizer 1998) these carbonate metasedimentary rocks offer important information on events coeval with the initial and final break-up of the Rodinia supercontinent $(\approx 1.0-0.75 \mathrm{Ga}$; Unrug 1997$)$ applicable to other cratons and belts of western Gondwana.

\section{The Frecheirinha ANd SÃo José Formations, CEArá}

The Middle Coreaú Domain, northwestern region of the state of Ceará is characterized by a series of grabens and horsts whose boundary faults trend SWNE. The sediments of the Ubajara Group were deposited in the Bambuí-Jaibaras Graben, which is delimited to the southeast by the Sobral-Pedro II shear zone (considered part of the shield-scale TransBrasiliano lineament, Caby et al. 1991). In the Martinópole graben, separated from the previous one by the Tucunduba horst (Fig. 9), sediments of the Martinópole Group, a possible correlative of the Ubajara Group, have been deposited.

The sedimentary carbonate rocks and subordinate pelites of the Frecheirinha Formation in the 


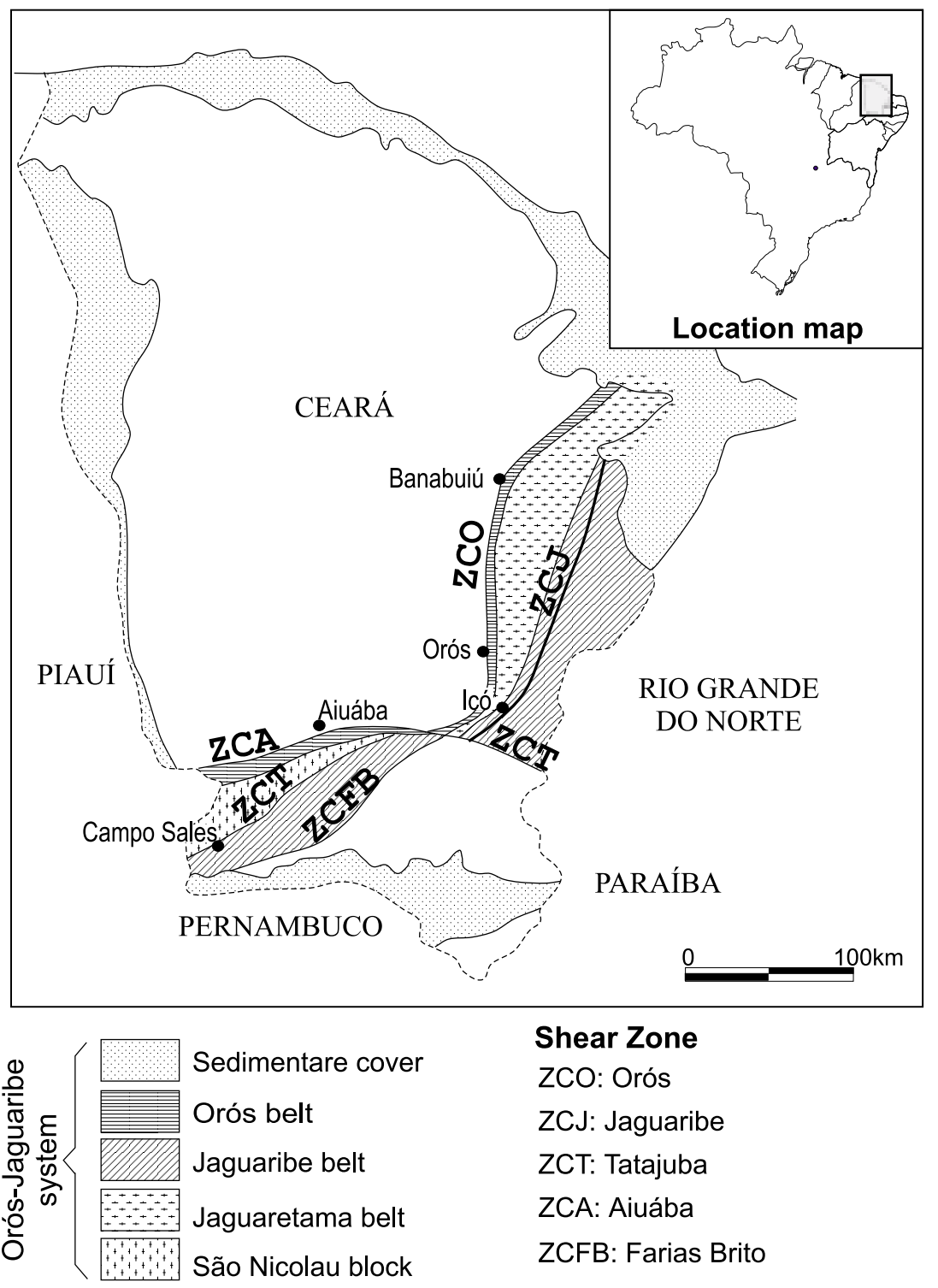

Fig. 8 - Simplified geologic map of the Orós Mobile belt, state of Ceará, northeastern Brazil (modified from Parente \& Arthaud 1995).

Ubajara Group have been considered for long time as sedimentary deposits correlative to carbonates of the Bambuí Group in central and eastern Brazil (Fig. 9). The Frecheirinha carbonates rest on red slates and quartzites of the Caiçaras Formation. Arkoses, graywackes and arkosic sandstones of the Coreaú Formation are found overlying the Frecheirinha carbonate rocks. The only inferred age for the Frechei- rinha Formation $(0.61 \mathrm{Ga})$ is based on a poor $\mathrm{Rb}-\mathrm{Sr}$ isochron (Novais et al. 1979) for clay fractions from slates of the underlying Caiçara Formation. The Mucambo pluton intruded Frecheirinha Formation carbonates at $0.54 \mathrm{Ga}$ developing a thermal aureole, and sets a minimum age for the Frecheirinha Formation. Mono-zircon fractions from the Saquinho meta-trachyandesite, near the Coreaú village, Ceará, 


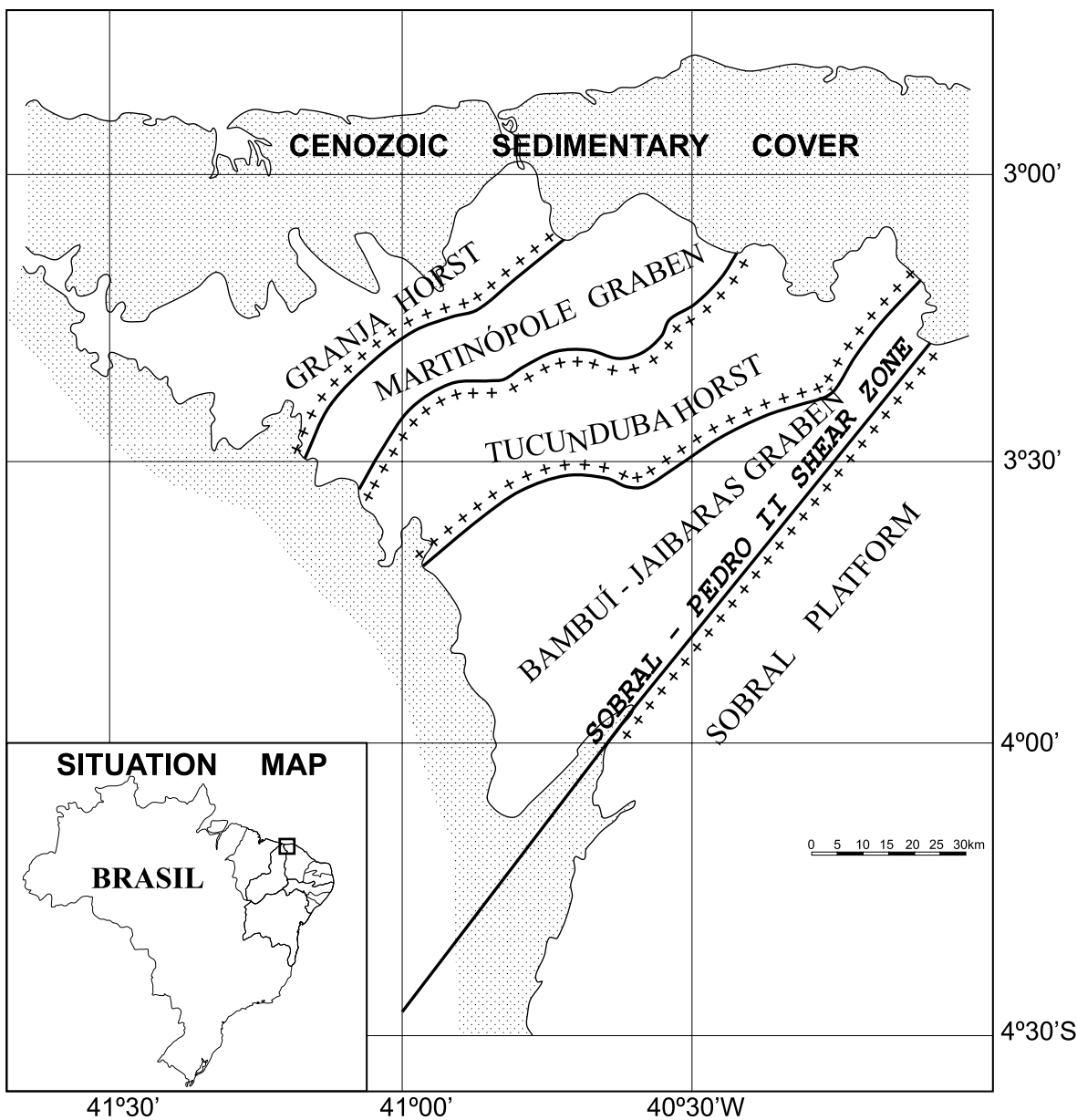

Fig. 9 - Simplified map of northwestern state of Ceará, NE Brazil, showing the location of the Bambui-Jaibaras (Ubajara Group), and the Martinópole (São José Formation) grabens separated by the Tucunduba horst.

in the Middle Coreaú domain yielded concordant plots with an upper intersect of $1.78 \mathrm{Ga}$ (Magini et al. 1999) interpreted as an indication of Statherian crystallization. This would imply a probable Late Paleoprotereozoic age for the Ubajara Group metasedimentary rocks, much older than previously supposed, something which requires further confirmation.

In the Martinópole graben, the low-grade metapelite-metapsamitic sequence of the Martinópole Group (schists, quartzites and slates) are overlain by magnesian limestones, graywackes, sandstones, ferruginous metacherts and metavolcanic rocks which have been regarded as the São José Group (Prado et al. 1979). The lithologic units of this Group are well represented in the São José hill, near the Ubatuba village about $70 \mathrm{~km}$ west of Granja village, in the northwerstern Ceará.

About 250 samples were taken on a meter scale over $\sim 100 \mathrm{~m}$ traverses across the strike of carbonate rocks of the Frecheirinha Formation, including samples from near the contact with the Caiçaras slates (bottom) and near the Coreaú sandstones (top). Marly limestones in the lowermost portion of this sequence are replaced upsection by fine-grained, almost pure, limestones $\left(\mathrm{CaCO}_{3}>85 \%\right)$. 


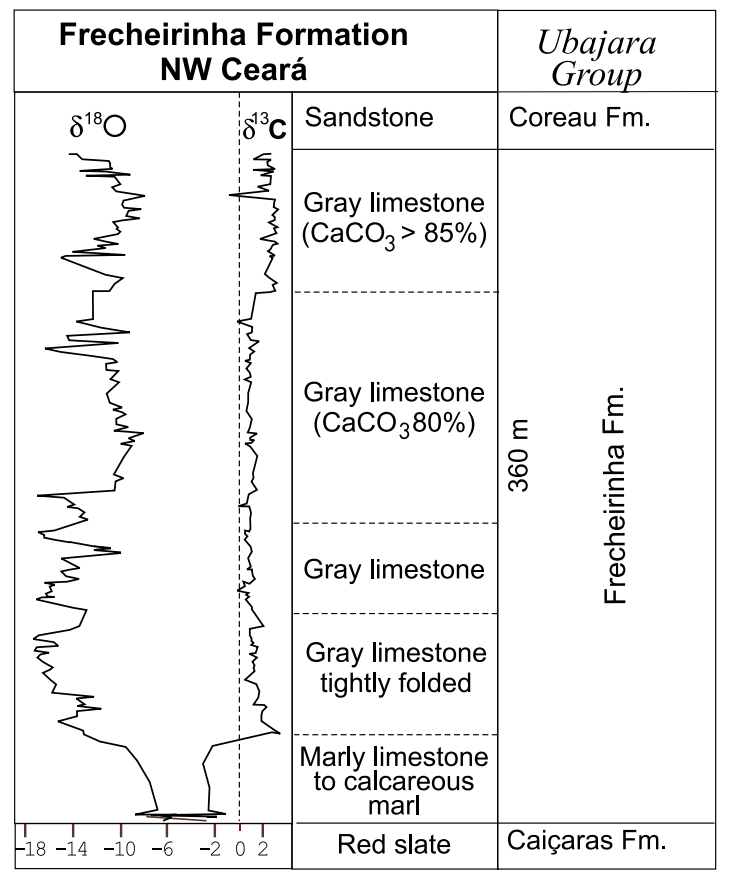

Fig. 10 - Composite oxygen and carbon isotope profiles for sedimentary carbonates of the Frecheirinha Formation, northwestern Ceará, NE Brazil.

The $\delta^{13} \mathrm{C}$ in four of the sampled sections is about $+1 \%$ opB while in the upper carbonate layers values jump to +2.5 to $+3.7 \%$ (Fig. 10). Similar $\delta^{13} \mathrm{C}$ pattern is also observed on the Paranoá Group gray carbonates which are about $1 \%$ \%DB (Santos et al. in press) and in the lower portion of the Bambuí Group limestones, jumps up to $+2.6 \%$ opDB increasing to $12 \%$ oupwards this unit (values as high as $+16 \%$ opDB for the upper Bambuí carbonates were reported elsewhere (Iyer et al. 1995, Santos et al. in press). In the light of the present C-isotope data, most marly limestones/limestones of the Frecheirinha Formation are isotopically equivalent to the Paranoá limestones, while the upper section of the Frecheirinha Formation is isotopically equivalent to the limestones of the lower Bambuí Group (no $\delta^{13} \mathrm{C}$ $>4 \%$ has been found in Frecheirinha Formation carbonates). $\delta^{13} \mathrm{C}$ for the marly carbonates at the lowermost portion of the Frecheirinha Formation is negative $(-8$ to $-1.2 \%$ o $\mathrm{PDB})$ coinciding with the highest $\delta^{18} \mathrm{O}$ values ( -6.9 to $-5.3 \%$ o $\mathrm{PDB}$ ) in the sequence. These marly carbonates were probably deposited under lower temperature conditions, in a post-glacial transition to a warmer climate.

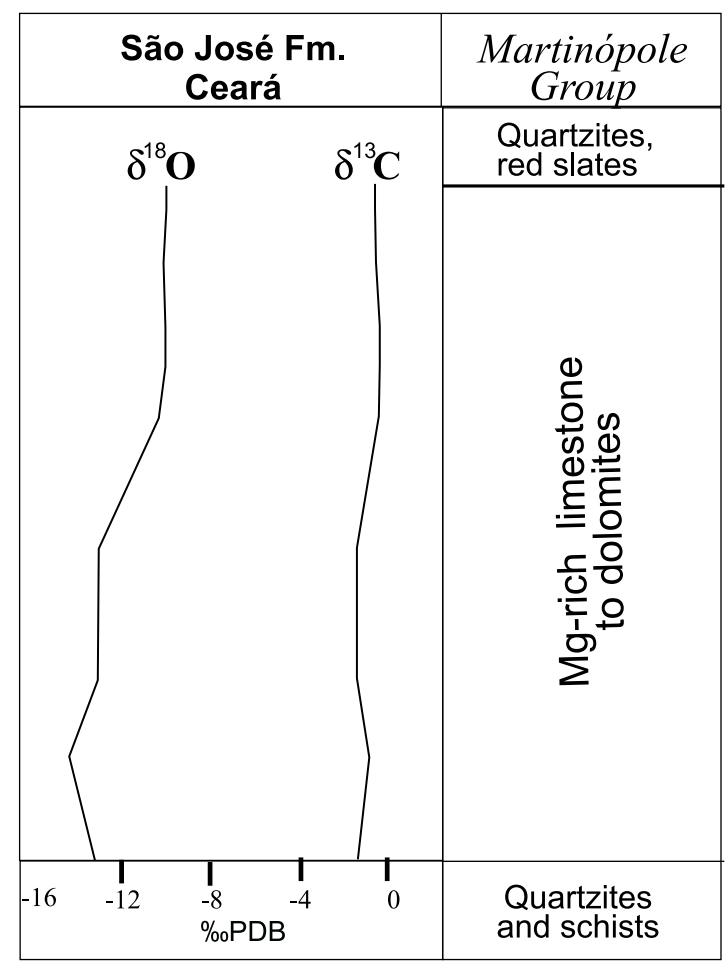

Fig. 11 - Oxygen and carbon isotope profiles for the São José Formation, northwestern Ceará, NE Brazil.

Ten samples of carbonates of the São José metasedimentary carbonates were collected at the São José hill. All these samples display $\delta^{13} \mathrm{C}$ between -1.5 (bottom of the section) and $-0.5 \%$ opB upsection, while $\delta^{18} \mathrm{O}$ varies from -14 (bottom) to $-10 \%$ орDB upsection (Fig. 11).

\section{The Jacoca, Acauñ and Olho D'Água For-} MATIONS, SERGIPE

The ESE-NNW trending Neoproterozoic, poly-deformed and poly-metamorphosed, Sergipano Foldbelt is part of the Borborema Province, at its southern border with the São Francisco Craton (Fig. 12). Detailed studies carried out by D'el Rey da Silva (1999) around the south-central part of this foldbelt 
and its interface with the northern margin of the São Francisco Craton demonstrated that sedimentation recorded the evolution of a passive continental margin and is divided into two cycles, each one comprising a continental to shallow marine, basal siliciclastic megasequence overlain by a carbonate sequence. The cratonic cover encompasses cycle I and part of the basal megasequence II. All of these rocks spread continuously across the craton margin into the Sergipano Foldbelt where they occur around the Itabaiana and Simão Dias basement domes and are overlain by a metadiamictite formation and a metacarbonate formation that complete cycle II. According to D'el Rey da Silva (1999), basement and cover underwent the same Neoproterozoic compressive deformation under sub-greenschist facies.

The lower siliciclastic megasequence is represented by the Juetê (arkosic sandstone, conglomerate lenses, diamictites), Itabaiana (conglomerates, quartzites, metasiltites) and Ribeirópolis (silty phyllites, metagreywackes, pebbly phyllites, diamictites) Formations and the lower carbonate megasequence is represented by the Acauã and Jacoca Formations. These two megasequences in cycle I comprise the Estância-Miaba Group.

The upper siliciclastic megasequence (Simão Dias Group) is represented by the Lagarto-Palmares (mudstones, siltstones, sandstones and lithic wackes), the Jacaré (metasiltites to metasandstones) and the Frei Paulo (silty phyllites with intercalations of metasandstones, metacarbonates and wackes) Formations. This megasequence is overlain by metasediments of the Vaza Barris Group that is comprised of diamictites of the Palestina Formation and the upper carbonate megasequence (Olho D’Água Formation).

The lower carbonate megasequence. The Acauã Formation conformably overlies the Juetê Formation and unconformably the basement gneiss (D'el Rey da Silva 1999). It consists of basal limestone, dolomite, calci-argillite with limestone lenses and layers of limestone and dolomites with intercalations of cross-bedded red sandstone and green argillite. In this study, twenty-one samples have been collected in a section of the Acauã carbonates with strata dipping about 300 northwestward, along the river at the Brejinho Farm, $10 \mathrm{~km}$ southeast of Lagarto town, state of Sergipe.

The Jacoca Formation overlies the pebbly phyllites/conglomerates of the Ribeirópolis Formation and comprises two lithofacies: metacarbonates and a mixed lithofacies of metasiliciclastics and metacarbonates (D'el Rey da Silva 1995). The metasedimentary carbonates are $<300 \mathrm{~m}$ thick around the Itabaiana dome (Fig. 13a) with the best exposures, in the Capitão farm, along the Salgado and Vaza Barris rivers southwest of the Macambira village, state of Sergipe.

A typical section of the Jacoca Formation as described in the Capitão Farm by D'el Rey da Silva (1995), starts with a thick layer of laminated white to gray, $1-3 \mathrm{~cm}$ thick beds of dolomites containing beds of pyrite and chalcopyrite. This is followed upsection by a $15 \mathrm{~m}$-thick layer of laminated dolomites, and dark gray to black phyllites and about 10m thick of massive dolomites. This unit is overlain by a $40 \mathrm{~m}$ thick sequence of gray limestones, calcarenites and dark gray to black phyllites. Finally, a sequence of gray metadolomites, $200 \mathrm{~m}$ thick, is observed.

In this study, about thirty-one samples of Jacoca carbonate from a section along the Vaza Barris River at the Capitão Farm, and twenty-one carbonate samples from the Acauã Formation at the Brejinho Farm, have been analyzed for carbon and oxygen isotopes and results are shown in Figure 13a, b.

In the Jacoca carbonates, $\delta^{13} \mathrm{C}$ varies from -6.4 to $-2.8 \%$ $\%$ PDB, with majority of the values near $-4 \%$ PDB as seen in Fig. 13a. $\delta^{18} \mathrm{O}$ values vary little, mostly around $-8 \%$ орDB. The $\delta^{13} \mathrm{C}$ in the Acauã carbonates, as in the Jacoca Formation, tend also to group around $-4 \%$ opD and $\delta^{18} \mathrm{O}$ has similar behavior to Jacoca carbonates with stronger oscillation of values upsection (Fig. 13b). The carbon isotopic behavior of these two sequences seems to favor the assumption that Acauã and Jacoca Formations were deposited contemporaneously (D'el Rey da Silva 1992) as well as that they probably 


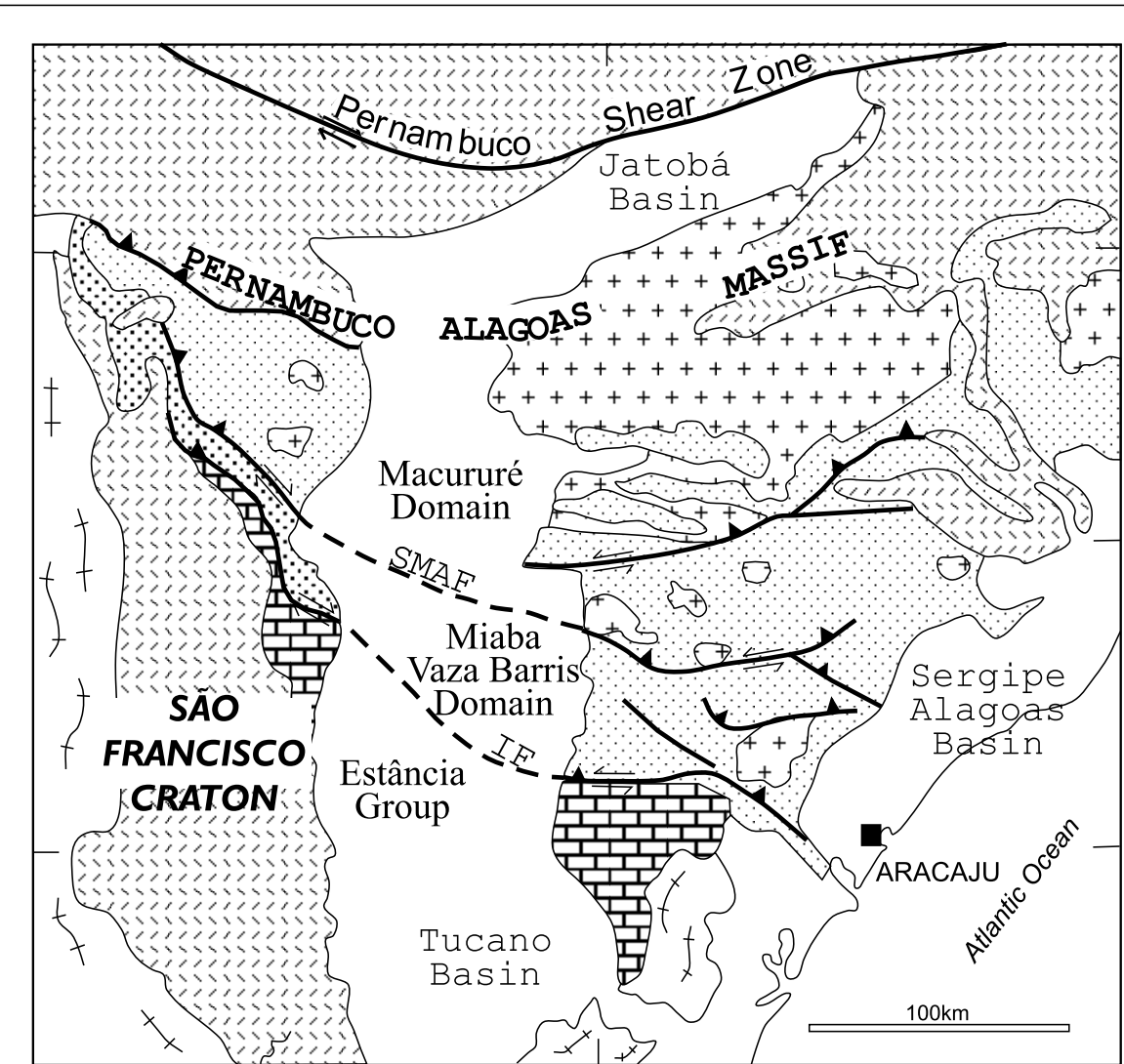

IF = Itaporanga fault

SMAF = São Miguel do Aleixo fault

\section{PHANEROZOIC}
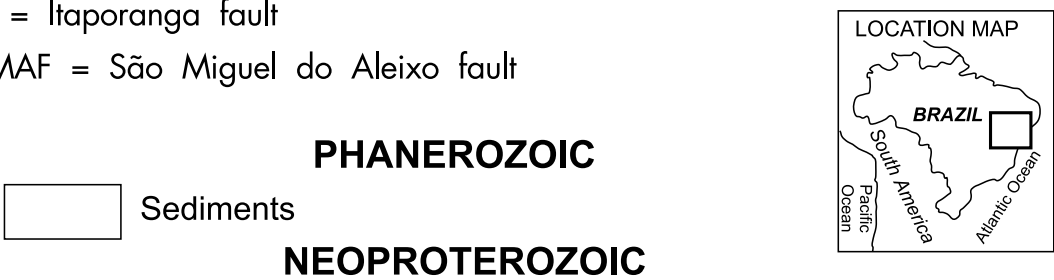

SOUTHERN BELT

$\because$ Polydeformed lowgrade metasediments

Cratonic sediments

\section{NORTHERN BELT}

++++
+++ Granites

Polydeformed, up to amphibolite grade metasediments, migmatites, and igneous rocks

\section{ARCHEAN TO PALEOPROTEROZOIC}

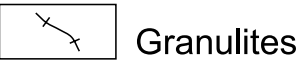

Amphibolite-grade gneisses

Fig. 12 - Simplified geologic map of the Sergipano Foldbelt fault (modified from D'el Rey da Silva 1992) showing the location of the Itabaiana dome (1) and Simão Dias dome (2) IF = Itaporanga fault; SMAF = São Miguel do Aleixo, NE Brazil. 


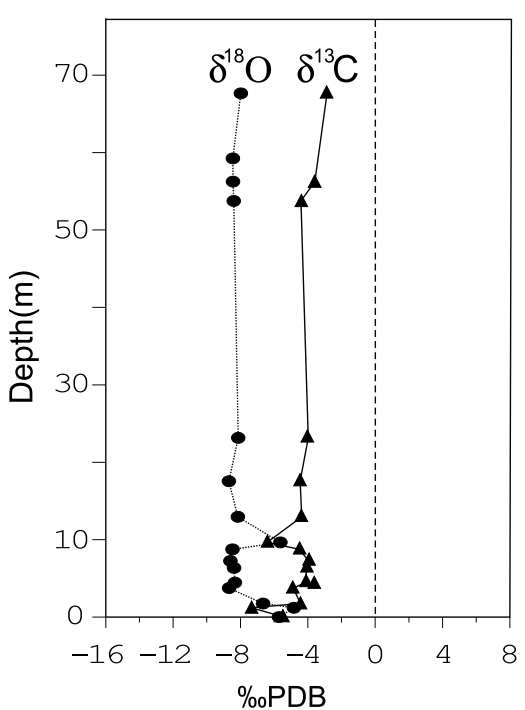

(a)

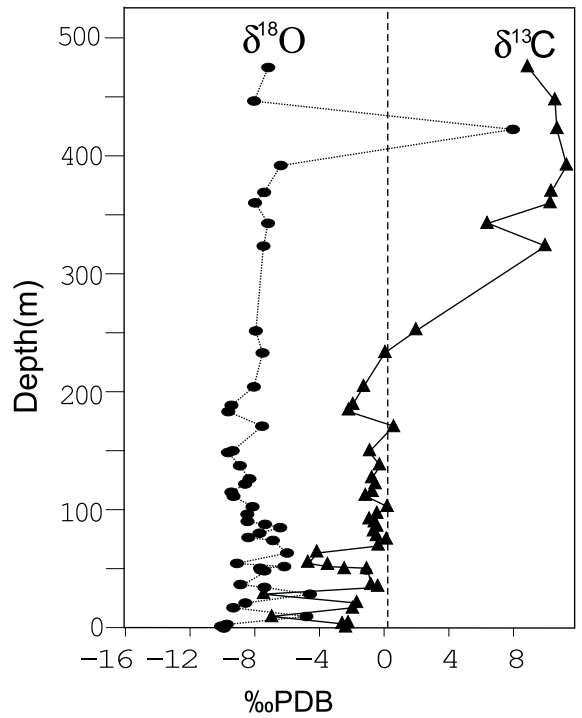

(c)

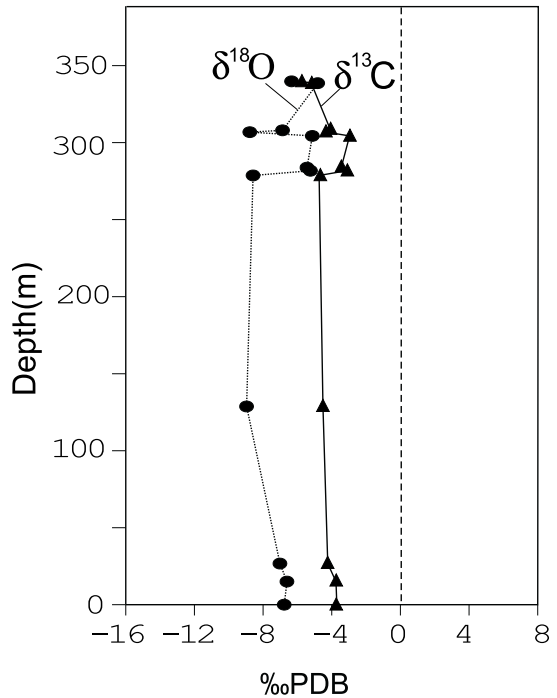

(b)

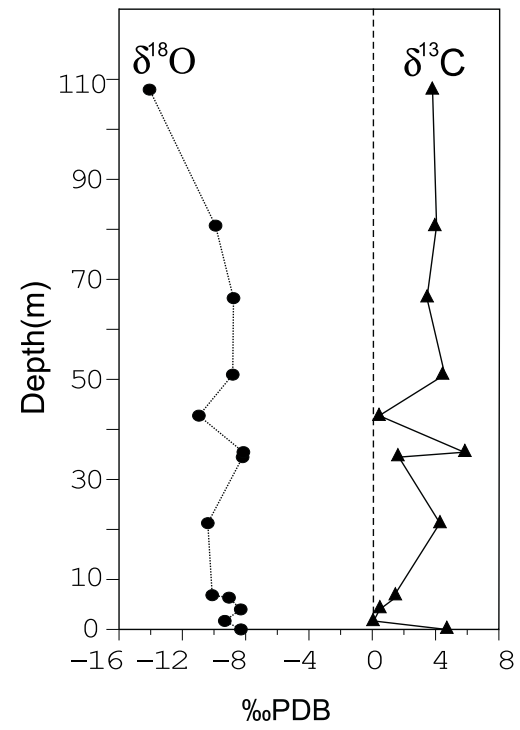

(d)

Fig. 13 - Carbon and oxygen isotope profiles: (a) Jacoca Formation; (b) Acauã Formation; (c) Olho D'Agua Formation (state of Sergipe) and (d) Traipu-Jaramataia Formation (state of Alagoas), NE Brazil.

correspond to cap carbonates sequences.

Five samples from a 10m-thick (meta) marl to marly carbonate lens intercalated in phyllites of the
Frei Paulo Formation, which underlies Palestina diamictites were collected north of the Pinhão locality near the junction with the road Carira-Frei Paulo. 
The $\delta^{13} \mathrm{C}$ varies from +3 to $+8 \%$ o PDB and from -9 to $-6 \%$ opDB.

The upper carbonate megasequence. The thick Olho D'Água Formation is composed of a sequence of marbles and interbedded green, calcareous chlorite-schists and silty phyllites of the Vaza Barris Group and overlies the thick diamictites, pebbly metagreywackes of the Palestina Formation. Marble beds are interbedded with blue to black, finegrained metalimestone and gray metadolomite. Individual marble beds vary from one to $40 \mathrm{~m}$ thick in the lower part of the Formation with only local one meter-thick beds in the upper part. Thicker and more abundant carbonate beds are observed in the south limb of the Pinhão anticline. The thick carbonates around the Simão Dias dome pass upward into supertidal-intertidal facies with oolites, and wavereworked structures indicating a near shore environment (D'el Rey da Silva 1992). Oolites to stromatolites are very rare, and reducing conditions predominated during the carbonate deposition. Stromatolites have been observed at Saco da Camisa locality (Cassedane \& Silva Filho 1982) and have been classified as stratifera undata, with a probable age between $1.0 \mathrm{Ga}$ and $0.55 \mathrm{Ga}$.

One hundred and twenty samples of Olho D'Água Formation were collected from $\sim 500$ meter of discontinuous outcrops across the southern limb of the Pinhão anticline, starting from the contact with the Palestina diamictite/pebbly metagreywackes. Marly carbonates at the basis of the sequence, near the contact with Palestina diamictites, display $\delta^{13} \mathrm{C}$ values as low as $-4.7 \%$ opDB, which increase upsection to values between zero and $1 \%$ opDB, and at the top change dramatically to values as high as $+10 \%$ opDB (Fig. 13c). This variation suggests that environmental conditions during deposition at the base of this sequence were different from those for carbonates at the top, allowing for an enormous $\mathrm{C}$-isotope oscillation. This $\delta^{13} \mathrm{C}$ trend on presumed cap carbonates, according to Kennedy (1996), would suggest that the Palestina diamictites would be correlatable to Sturtian glacial episode.
Oxygen isotopes show a more limited variation with $\delta^{18} \mathrm{O}$ values ranging from -7 to $-10 \%$ PDB .

\section{The Traipu-Jaramataia Formation, Alagoas}

The Macururé tectonic domain (state of Alagoas, northern part of the Sergipano foldbelt; Fig. 12) is separated from the Miaba-Vaza Barris Domain, described above, by the São José do Aleixo shear zone. While the carbonate to clastic sediments of the Miaba-Vaza Barris Domain were mono-deformed and subject to greenschist-facies metamorphism, the Macururé Domain metasediments were polydeformed and mostly metamorphosed at the amphibolite facies.

The Traipu-Jaramataia Formation of the Macururé Group is characterized by a sequence of metagreywackes, metasiltstones, metashales and minor metasedimentary carbonates (marbles), besides felsic, basaltic and ultrabasic igneous rocks metamorphosed in the amphibolite facies. Narrow and elongate carbonate lenses are observed along the Belo Monte Fault zone and near the road between Batalha town and Capivara village.

About twenty-five carbonate samples have been collected at a metric scale across the strike of a representative $80 \mathrm{~m}$-thick lens by the point where the road Batalha-Capivara branches off to the Jaramataia village. These marbles are usually coarsegrained, banded, pink to white, with intercalated mica-rich layers (locally with epidote), intercalated in a garnet-rich biotite-schist. The $\delta^{13} \mathrm{C}$ values in this Formation are always positive (Fig. 13d) and most of them are in the +3 to $+4 \%$ o behavior which totally differ from that observed in the Jacoca and Acauã carbonates. This suggests that the Traipu-Jaramataia carbonate rocks have been deposited at a different time in relation to the Acauã and Jacoca Formations in the state of Sergipe.

\section{CONCLUSIONS}

The $\mathrm{C}$ isotope data presented and discussed here provide some important insights on Precambrian sedimentary carbonate sequences from some localities 
in Brazil and may become useful for future inter and intra-basinal correlations. Interpretations here are, however, mostly preliminary and require, in some cases, further detailed studies.

Carbon isotopes in the carbonate-rich jaspilites of the Archean Carajás (BIF) Formation demonstrate that, as in the majority of Archean carbonates, they have acquired a mantle signature through carbonatization of a silicate protolith by a $\mathrm{CO}_{2}$-rich fluid from mantle degassing; or equilibrium with a deep basinal water with a composition around $-5 \%$ PDB.

Carbonates of the Paleoproterozoic Gandarela Formation display a $\mathrm{C}$-isotope oscillation within the worldwide secular variation, and the Fecho do Funil Formation seems to record the positive $\delta^{13} \mathrm{C}$ Lomagundi (Jatulian) anomaly, a contention which requires further investigation.

The $\mathrm{C}$ isotope fluctuations in the studied Neoproterozic metasedimentary carbonate sequences in northeastern Brazil lead to the following inferences, when the secular $\delta^{13} \mathrm{C}$ variation in the Neoproterozoic (Fig. 1) is taken into account:

1. The $\mathrm{C}$ isotope pattern for the Frecheirinha Formation with $\delta{ }^{13} \mathrm{C}$ values around -1 to $-2 \%$ орDB and positive values around +2 to $+3 \%$ PDB is compatible with a deposition around $0.98 \mathrm{Ga}$. A similar $\mathrm{C}$ isotopic behavior has been observed in Paranoá carbonates in central Brazil (Santos et al. in press) and it is possible that these two units have been synchronously deposited.

2. The Jacoca-Acauã Formations, according to their $\delta^{13} \mathrm{C}$ oscillations seem to have been deposited around $0.76 \mathrm{Ga}$, on top of diamictites (Ribeirópolis, Jacarecica Formations). Values of $\delta^{13} \mathrm{C}$ around $-4 \%$ PDB are observed in both Formations and no positive $\delta^{13} \mathrm{C}$ values have been recorded from either one.

3. Metacarbonate lenses of the Frei Paulo Formation show positive $\delta^{13} \mathrm{C}$, averaging $+5 \% \mathrm{PDB}$, and a deposition age around $0.74 \mathrm{Ga}$ can be inferred.

4. The Olho D'Água carbonate sequence shows $\delta^{13} \mathrm{C}$ around $-4 \%$ opdB at the base of the Formation, and values around $+9 \%$ o $\mathrm{PDB}$, at the top, consistent with a cap carbonate deposition around $0.69 \mathrm{Ga}$ on the Capitão-Palestina diamictites.

All Neoproterozoic carbonate sequences in this study, some of which have been previously regarded as chronocorrelatable to the Bambuí Group carbonates, seem, based on their carbon isotope behavior, to be older than this Group. The Bambuí Group displays $\delta^{13} \mathrm{C}$ values as high as $+16 \%$ opdB (Iyer et al. 1995, Santos et al. in press) or even higher in the top carbonate Formations, which we interpret as indication of a Post-Sturtian deposition, around 0.60 Ga. A similar age (595 $\pm 5 \mathrm{Ma}$ ) has been recently proposed by Kawashita (1999), based on the behavior of the ${ }^{87} \mathrm{Sr} /{ }^{86} \mathrm{Sr}$ for the Bambuí carbonates and in a secular variation curve for the Neoproterozoic.

\section{ACKNOWLEDGEMENTS}

Field and laboratory works were supported in part by a PADCT/FINEP project (65.930.619-00). We thank three anonymous reviewers whose comments and suggestions helped to improve an earlier version of this manuscript. Thanks are also due to Gilsa M. Santana and Vilma Sobral Bezerra for the assistance with carbon and oxygen isotope analyses at the Stable Isotope Laboratory (LABISE) in the Federal University of Pernambuco, Brazil. This is the contribution n.172 of the NEG-LABISE.

\section{REFERENCES}

Aceñolaza FG \& Durand FR. 1987. Paleontologia del limite Precámbrico-Cámbrico de Argentina. X Congreso Geológico Argentino, Actas, 1: 315-320.

Babinski M, Chemale JR F \& Van Schmus WR. 1995. $\mathrm{The} \mathrm{Pb} / \mathrm{Pb}$ age of the Minas Supergroup carbonate rocks, Quadrilátero Ferrífero, Brazil. Precamb Res 72: 235-245.

BAKer AJ \& FAllick AE. 1989a. Evidence from Lewisian limestone for isotopically heavy carbon in two-thousand-million-year-old sea water. Nature 337: $352-354$

BAKer AJ \& FAllick AE. 1989b. Heavy carbon in two billion-year-old marbles from Lofoten-Vesteralen, 
Norway: implications for the Precambrian carbon cycle. Geochim Cosmochim Acta 53: 1111-1115

Beukes NJ, Klein C, Kaufman AJ \& Hayes JM. 1990. Carbonate petrography, kerogen distribution, and carbon and oxygen isotope variations in an Early Proterozoic transition from limestone to iron-formation deposition, Transvaal Supergroup, South Africa. Econ Geol 85: 663-690.

Bowins RJ \& CRocket JH. 1994. Sulfur and carbon isotopes in Archean banded iron formations: implications for sulfur sources. Chem Geol 111: 307-323.

Buick IS, Uken R, Gibson RL \& Wallmach T. 1998. High ${ }^{13} \mathrm{C}$ Paleoproterozoic carbonates from the Transvaal Supergroup, South Africa. Geol 26: 875878.

Caby R, Sial AN, Arthaud M \& Vauchez A. 1991. Crustal evolution and the Brasiliano Orogeny in Northeast Brazil. In: Dallmeyer, RD \& LÉCORCHÉ, J/P. (eds): The West African Orogens and CircumAtlantic Correlatives, Springer-Verlag: 373-397.

Cassedane JP \& Silva Filho MA. 1982. Stromatolite do Saco de Camisa (Sergipe). An Acad Bras Ci 54: 429-439.

D'el Rey Silva LJH. 1992. Tectonic Evolution of the Southern Part of the Sergipano Fold Belt, NE Brazil. Univ. of London, Ph.D. Dissertation, 258p.

D'el Rey Silva LJH. 1995. The evolution of basement gneiss domes of the Sergipano fold belt (NE Brazil) and its importance for the analysis of Proterozoic basins. Jour South Amer Earth ci 8(3/4): 325-340.

D'el Rey Silva LJH. 1999. Basin in-filling in the southern-central part of the Sergipano Belt (NE Brazil) and implications for the evolution of Pan-African/Brasiliano cratons and Neoproterozoic sedimentary cover. Jour South Amer Earth ci 4-5(2): 1-18.

Emrich K, Ehhalt DH \& Vogel JC. 1970. Carbon isotope fractionation during the precipitation of calcium carbonates. Earth Plan. Sci Letters 8: 363-371.

Hoffman PF \& Schrag DP. 2000. Snowball Earth. Sci American, January: 50-57.

Hoffman PF, Kaufman AJ \& Halverson GP. 1998a. Comings and goings of global glaciations on a Neo- proterozoic tropical platform in Namibia. GSA Today 8(5): 1-10.

Hoffman PF, Kaufman AJ, Halverson GP \& Schrag DP. 1998b. A Neoproterozoic Snowball Earth. Science 281: 1342-1346.

Inda HV, Schorscher HD, DardenNe MA, Schobbenhaus C, Haralyi NLE, Branco PCA \& Ramalho R. 1984. O craton de São Francisco e a Faixa de Dobramentos Araçuai: In: C Schobbenhaus, DA Campos, GR Derze \& HE Asmus (editors), Geologia do Brasil, DNPM, Brasília, 193-248.

Iyer SS, Babinski M, Krouse HR \& Chemale F. 1995. ${ }^{13} \mathrm{C}$-enriched carbonate and organic matter in the Neoproterozoic sediments of the Bambuí Group, Brazil. Precamb Res 73(1,2,3,4): 271-282.

Kaufman AJ. 1998. Neoproterozoic chemostratigraphy: key events in Earth history ordered by detailed intra- and inter-basinal correlation. XL Congresso Brasileiro de Geologia, Belo Horizonte, p.2.

Kawashita K. 1999. Datação de rochas carbonáticas: Grupo Bambuí como exemplo. An Acad Bras $C i$ 71(4-II): 1037-1038.

Kennedy MJ. 1996. Stratigraphy, sedimentology, and isotopic geochemistry of Australian Neoproterozic Postglacial cap dolostones: deglaciation, $\delta^{13} \mathrm{C}$ excursions, and crabonate precipiation. J Sedd Research 6(66): 1050-1064.

Kha LC, Sherman AG, Narbonne GM, Knoll AH \& Kaufman AJ. 1999. $\delta^{13} \mathrm{C}$ stratigraphy of the Proterozoic Bylot Supergroup, Baffin Islands, Canada: implications for regional lithostratigraphy correlations. Can Jour Earth Sci 36: 313-332.

Knoll AH, Hayes JM, Kaufman AJ, Swett K \& LamBERT IB. 1986. Secular variations in carbon isotope ratios from Upper Proterozoic successions of Svalbard and East Greenland. Nature 321: 832-838.

Kushy TM \& HudLeston PJ. 1998. Growth and demise of an Archean carbonate platform, Steep Rock Lake, Ontario, Canada. Can Jour Earth Sci 36: 565-584.

Machado N, Lindenmayer Z, Krogh TE \& LindenMAYER D. 1991. U-Pb geochronology of Archean magmatism and basement reactivation in the Cara- 
jás area, Amazon shield, Brazil. Precamb Res 49: 329-354.

Magini C, Santos TC, Brito Neves BB, Hackspacher PC, Van Schmus WR, Dantas E \& Fetter A. 1999. Statherian Taphrogenesis in the Borborema Province, NE Brazil. Actas II South American Symposium on Isotope Geology, Cordoba, Argentina: 327-329.

Maheshwari A, Sial AN \& Chittora VK. 1999. High Paleoproterozoic carbonates from the Aravalli Supergroup, Western India. Intern Geol Review 41: 949954.

McCrea JM. 1950. On the isotope chemistry of carbonates and a paleotemperature scale. Jour Chem Phys 18: $849-857$.

Melezhik VA \& Fallick AE. 1994. A worldwide 2.22.0 Ga-old positive $\delta^{13} \mathrm{C}$ anomaly as a phenomenon in relation to the Earth's major paleoenvironmental changes. Miner Mag 58a: 593-594.

Melezhik VA, Fallick AE, Makharikhin V \& LyubTSOV VV. 1997. Links between Paleoproterozoic paleogeography and rise and decline of stromatoilites: Fennoscandian Shield. Precamb Res 82: 311-348.

Misi A \& Veizer J. 1998. Neoproterozoic carbonate sequences of the Una Group, Irecê Basin, Brazil: chemostratigraphy, age and correlations. Precamb Res 89: 87-100

Novais FRG, Brito Neves BB \& Kawashita K. 1979. Reconhecimento cronoestratigráfico na região Noroeste do Ceará. Atas IX Simpósio Geol. Nord., Natal, pp. 93-110.

Parente CV \& Arthaud MH. 1995. O sistema OrósJaguaribe no Ceará-NE do Brasil. Revista Brasileira de Geociências 25(4): 297-305.

Prado FS, Mendonça JCG, Moprais JBA, Medeiros MF, AssunÇÃo PRS, ANDRAdE VA \& MEdEIRos RP. 1979. Relatório Final do Projeto Martinópole. Companhia de Pesquisa de Recursos Minerais, SUREGRecife: 63-75.

Santos RV, Alvarenga CJS, Dardenne MA, Sial AN \& Ferreira VP. Carbon and oxygen isotope profiles across Neoproterozoic limestones from central Brazil: Bambuí and Paranoá groups. Precamb
Res (in press).

Schidlowski M, Eichmann R \& Junge CE. 1976. Carbon isotope geochemistry of the Precambrian Lomagundi carbonate province, Rhodesia. Geochim Cosmochim Acta 53: 859-871.

Scholle PA \& Arthur MA. 1980. Carbon isotope fluctuations in Cretaceous pelagic limestones: potential stratigraphic and petroleum exploration tool. $A A P G$ Bull 64: 67-87.

Teixeira JB, Ohmoto H \& Eggler DH. 1997. Elemental and oxygen isotope variations in Archean mafic rocks associated with the Banded Iron-Formation at the N4 Iron Deposit, Carajás, Brazil. In: Costa, ML \& AgElicA, RS. Contribuições à Geologia da Amazônia, 161-203.

Trompette R. 1994. Geology of Western Gondwana. Balkema, 350pp.

UNRUG R. 1997. Rhodinia to Gondwana: the Geodynamic Map of Gondwana Super-continent Assembly. GSA Today 7: 1-5.

Van Schmus WR, Brito Neves BB, Hachspacher P \& BABINSKI M. 1995. U/Pb and $\mathrm{Sm} / \mathrm{Nd}$ geochronologic studies of the Eastern Borborema Province, Northeastern Brazil: initial conclusions. Jour South Amer Earth ci 8(3/4): 267-288

VeIzer J \& Hoefs J. 1976. The nature of $\mathrm{O}^{18} / \mathrm{O}^{16}$ and $\mathrm{C}^{13} / \mathrm{C}^{12}$ secular trends in sedimentary carbonate rocks. Geochim Cosmochim Acta 40: 1387-1395.

Veizer J, Hoefs J, Ridler RH, Jensen LS \& LOWE DR. 1989a. Geochemistry of Precambrian carbonates: I. Archean hydrothermal systems. Geochim Cosmochim Acta 53: 845-857.

Veizer J, Hoefs J, Lowe DR \& Thurston PC. 1989b. Geochemistry of Precambrian carbonates: II Archean greenstone belts and Archean sea water. Geochim Cosmochim Acta 53: 859-871.

Veizer J, Clayton RN, Hinton RW, Von Brunn V, Mason TR, Buck SG \& Hoefs J. 1990. Geochemistry of Precambrian carbonates, 3. Shelf seas and non-marine environments of the Archean. Geochim Cosmochim Acta 54: 2717-2729. 